\title{
Introduction \\ The Grassroots Right in Latin America: Patterns, Causes, and Consequences
}

\author{
Lindsay Mayka \\ Amy Erica Smith
}

\begin{abstract}
A fter a decade of leftist governments, the Latin American right is resurgent. While rightist and center-rightist politicians and parties have come to power in a number of countries, the shift is most significant at the grassroots. This special section of Latin American Politics and Society is dedicated to understanding the "grassroots right": the diverse citizens, civil society associations, and religious groups engaged in activism to support right-wing issues. Their causes range from restricting abortion, affirmative action, and LGBTQ+ rights to expanding gun rights and violently repressing crime to supporting free markets and opposing redistribution.

We know too little about the grassroots right in contemporary Latin America. Recent work on civil society in the region has focused mostly on left-leaning groups that mobilize for social and economic rights. For instance, a rich literature has developed to study feminist movements (Baldez 2002; Blofield 2008; Daby and Moseley 2021; Htun 2003; Thayer 2009), LGBTQ+ rights movements (Díez 2015; Encarnación 2016), environmentalists (Herrera and Mayka 2020; Hochstetler and Keck 2007), Black and Indigenous rights movements (Lucero 2008; Paschel 2016; Yashar 2005), and rights-based health movements (Gibson 2019; Mayka 2019; Niedzwiecki and Anria 2019; Rich 2019).

Meanwhile, most existing studies of the right have focused on electoral participation and party organizations. These studies have analyzed the public opinion foundations behind voters' support of right-wing parties and candidates (Samuels and Zucco 2018; Wiesehomeier and Doyle 2014; Layton et al. 2021), changes in the linkage strategies and targeted appeals used by parties on the right to woo voters
\end{abstract}

Lindsay R. Mayka is an associate professor of government at Colby College, Waterville, Maine, USA. lrmayka@colby.edu. ORCID: 0000-0002-8967-4735. Amy Erica Smith is Liberal Arts and Sciences Dean's Professor and associate professor of political science, as well as a Carnegie Fellow, at Iowa State University, Ames, Iowa, USA. aesmith2@iastate.edu. ORCID 0000-0002-6436-153X. We declare no conflicts of interest.

(C) The Authors, 2021. Published by Cambridge University Press on behalf of the University of Miami. This is an Open Access article, distributed under the terms of the Creative Commons Attribution license (http://creativecommons.org/licenses/by/4.0/), which permits unrestricted re-use, distribution, and reproduction in any medium, provided the original work is properly cited. DOI 10.1017/lap.2021.20 
(Holland 2013; Luna 2014), strategies to build right-wing parties (Loxton 2016; Vommaro et al. 2015), and the relationship between right-wing parties and democracy (Gibson 1996; Middlebrook 2000; Roberts 2014). Yet right-wing mobilization happens through both electoral and nonelectoral channels (Bowen 2014; Eaton 2014; Luna and Rovira Kaltwasser 2014a, 13-14).

This introductory essay poses four sets of questions on the nature, origins, and impacts of the grassroots right in Latin America. First, what is the grassroots right? We identify the range of issues, identities, and claims embraced by the grassroots right in contemporary Latin America. What unites them, we argue, is an affirmation of traditional social hierarchies, whether patriarchal, heteronormative, cisgender, economic, religious, or ethnic and racial, often defined in reaction against progressive social actors seeking to level them.

After conceptualizing and providing a brief overview of the grassroots right, we proceed to several subsequent questions. Second, how does the grassroots right mobilize? What organizational forms, repertoires, and frames does it employ? We show that the grassroots right adopts a range of mobilizing structures, from formal organizations to loose networks. Furthermore, it has adapted many of the strategies, tactics, and frames historically used by left-wing movements and repurposed them to new aims.

Third, what has caused the recent rise in grassroots right mobilization? We sketch out several sets of hypotheses explaining the recent growth of the grassroots right: secular societal change and democratization; new grievances and perceived threats, especially in countries governed by the left during the Pink Tide; an expanded infrastructure for mobilizing via Evangelical churches and social media; and international diffusion.

Fourth, what is the impact of the grassroots right on policy and democracy? We highlight the movement's mixed record in achieving its objectives and develop hypotheses to explain variation in its impact.

In addressing these questions, we draw on a growing body of existing scholarship on rightist mobilization in Latin America and globally. We also reflect on the four excellent essays in this special section, which represent cutting-edge perspectives on the grassroots right in the region. Together, these articles shine new light on key questions about the roots of right-wing mobilization, policy change, and the relationship between the right and democracy in Latin America.

\section{WHAT IS THE GRASSROOTS RIGHT?}

Scholars generally take one of two approaches to defining this object of study, emphasizing either the actors (the who), or their issues (the what). In the former category, for instance, is Timothy Power's 2000 volume on The Political Right in Postauthoritarian Brazil, which defines the right as an "exceedingly large and diverse" set of actors, including "the armed forces, large- and medium-sized landowners, and elements of the industrial bourgeoisie, as well as smaller segments of the Catholic hierarchy, the middle classes, and the media," plus Brazil's authori- 
tarian successor parties (36-37). Following Power, as well as Edward Gibson (1996) and Kevin Middlebrook (2000), James Bowen identifies the right by its "core constituencies": "the upper economic and social strata of society," termed "elites" $(2011,105-6)$. Yet in a study of the grassroots, such a definition is unsatisfying; it suggests that nonelites cannot mobilize behind rightist politics. To be sure, Bowen (2011, 5-6) acknowledges that populist politicians can mobilize ordinary citizens to support the right, yet this approach implies an assumption of false consciousness within the "grassroots right" that we do not believe is justified ex ante.

Instead, we focus on the what - the issues and ideologies that rightists champion. This approach avoids oversimplifying the interests of entire social groups or classes, instead inquiring into what political actors themselves want. However, it poses a different challenge: to find the thread tying together the extraordinarily diverse issues that rightists champion, which include everything from opposing citizen access to abortion to supporting citizen access to guns. What principle unifies those demands?

In one attempt to answer that question, Luna and Rovira Kaltwasser (2014a, 4) put forth a clear, flexible, and expansive definition of the right as "a political position distinguished by the belief that the main inequalities between people are natural and outside the purview of the state." The strength of this definition is its capacity to describe neatly the right's stances on wide-ranging economic and racial issuesareas where the left historically has championed governmental action to redress inequalities. Yet this definition is less apt for describing rightist versus leftist stances on issues such as gay rights and abortion, for which contemporary rightists may actually advocate government policy to enforce inequality or to prevent access to services that could be provided via markets, such as abortion or prostitution. Given the centrality of sexuality politics for Latin America's "neoconservatives" or "New Right," we need a definition that adequately incorporates such stances (Côrrea et al. 2008; Cowan 2014; Lacerda 2019; Vaggione and Machado 2020).

Therefore, we define the right as a diverse set of individuals and organizations aiming to maintain societal hierarchies that are perceived as traditional or natural. This definition differs from that of Luna and Rovira Kaltwasser (2014a) in that it centers rightists' proactive defense of hierarchies rather than their opposition to government action. Such hierarchies might include, for instance, patriarchy, the economic dominance of large businesses or landowners, or the subordination of LGBTQ+ individuals or Black and Indigenous Latin Americans.

At the same time, as Eaton (2014) notes, Latin America's right is no longer invested simply in championing discrete issues. Instead, the right has begun "engaging in deeper and ongoing projects of identify formation," deploying "discursive and rhetorical practices that seek to transform political identities" $(2014,87)$. Although Eaton focuses on sectoral and territorial identities, by 2021 the rightist project of identity formation has deepened and politicized identities ranging from religious to nationalist to antipartisan. Our definition of the right highlights its potential to advance a transformative agenda to entrench inequalities, which conceives of rightists as the true defenders of the traditional moral order. 
When discussing the grassroots right, we refer to the citizens and civil society groups that engage in activism to support rightist issues and identities. ${ }^{1}$ Scholarship on the Latin American right has historically centered political elites, including politicians and governmental actors such as the military (Luna and Rovira Kaltwasser 2014a; Power 2000). However, Latin America's rightward turn in the 2010s was particularly striking among citizens. While rightists of various stripes captured the presidency in a number of countries-from Brazil's far-rightist Jair Bolsonaro to Chile's technocratic center-rightist Sebastián Piñera-nearly every country in the region witnessed prominent movements advocating for conservative positions on issues such as sexuality politics. The emergence of these movements signals that grassroots mobilization can come from a range of socioeconomic backgrounds-not just the subaltern groups traditionally associated with leftist social movements.

This is not to say that current rightist movements are entirely novel in Latin America. Prominent right-leaning social movements of the twentieth century included conservative women's movements (Baldez 2002) and militarized groups, such as armed landowners in Brazil (González and Kampwirth 2001; Payne 2000). Still, the grassroots right has flourished since the turn of the millennium, in both volume of mobilization and societal prominence.

We distinguish Latin America's grassroots right from two related concepts. First, it is not simply a mass public following elite direction; rightist citizens are independent actors, whose views and behavior are not reducible to their relationship with politicians. Thus, the grassroots right extends beyond-but interacts withrightist party organizations and electoral activism. Likewise, the grassroots right cannot be reduced to a top-down, "AstroTurf" dynamic, with participation simply manufactured by elites. Second, Latin America's grassroots right often takes the form of social movements, yet it may also defy traditional understandings of movements. Its organizational forms range from formal or informal social movements to religious congregations and denominations, or sporadic mobilization in contentious action among people who do not know each other and are linked only through social media, as emphasized in the article in this volume by Dias, von Bülow, and Gobbi, as well as the article by Gold and Peña.

In practice, what does Latin America's grassroots right look like? Perhaps the single set of issues distinguishing the right today from that in previous periods is the centrality of sexuality politics; for instance, opposition to abortion, LGBTQ+ rights, and school-based sexual education (Biroli and Caminotti 2020; Pérez Betancur and Rocha-Carpiuc 2020; Vaggione and Machado 2020; Zaremberg 2020). In this section, for instance, Corredor and Reuterswärd describe movements opposing "gender equality" in Colombia and abortion access in Mexico, respectively. As Corredor (2019; this issue) argues, opposition to what rightists call "gender ideology" has emerged as a powerful counterframe that enables Latin America's grassroots right to contest the sexual empowerment of lower-status groups. This counterframe derailed public school sexual education initiatives in countries such as Brazil and Peru (Payne and de Souza Santos 2020; Rousseau 2020) and has even been harnessed to attack seemingly unrelated projects, such as Colombia's peace process (Corredor this issue). 
One reason sexuality politics has become a magnetic core for the right is that these issues have unique power to mobilize religious conservatives-both Catholics and the growing body of conservative Evangelicals (Smith 2019a; Smith and Boas 2020).

While no topic has aroused more attention than sexuality politics, the grassroots right mobilizes around many other issues. Most classically, it may oppose social policies benefiting marginalized groups, such as conditional cash transfers and affirmative action in Brazil (e.g., Côrrea 2015; Feres Júnior and Toste Daflon 2015). Relatedly, the regional autonomy movement in Santa Cruz, Bolivia arose in reaction against the Evo Morales administration's efforts to empower Indigenous Bolivians and redistribute resources across regions (Bowen 2014; Eaton 2007). Similarly, Argentina's agricultural producers revolted against an export tax hike to fund social programs during the administration of Cristina Fernández de Kirchner (Fairfield 2011). In all these cases, rightist civil society actors mobilized to defend in-group economic interests, opposing redistributive policies under leftist administrations.

Another area of rightist mobilization relates to security and crime, when citizens organize to support mano dura or "tough on crime" policies. Examples include mobilization to demand repressive policing of marginalized groups in São Paulo (González and Mayka n.d.), movements for gun rights in Brazil (Bob 2012, chap. 6), and organized opposition to police reform in Argentina (Eaton 2008, 22-25). Mobilization also has taken a distinctively international dimension as rightists oppose the specter of creeping communism and Chavismo, with Cuba and Venezuela serving as effective bogeymen in arousing opposition throughout the region.

Because the right's objectives are socially constructed and contextual, its salient issues and identities vary across space and time. For instance, the European right tends to target immigrants to a greater extent than the Latin American right, which instead focuses on dark-skinned and lower-class internal enemies, such as bandidos in slums. Thus the constellation of issues and identities that characterizes the grassroots right in twenty-first-century Latin America is not definitional to the right. Instead, rightist activists can be identified via their general opposition to state intervention to dismantle existing inequalities and their support for a "traditional" social order.

It is important to distinguish the rise of the grassroots right from two other recent trends in Latin America: autocratization and populism. In some cases, these three trends go together: most notably in the Brazilian movement leading to the downfall of Dilma Rousseff and the rise of Jair Bolsonaro (Dias et al. this volume; Gold and Peña this volume; Cohen et al. Forthcoming; Layton et al. 2021). Grassroots right mobilization also coincided with authoritarianism in the 2019 movement overturning Evo Morales's disputed electoral victory, which led to the oneyear right-wing rule of Jeanine Áñez in Bolivia. Nevertheless, support for authoritarianism and populism are uncorrelated with rightism; in recent years, right-wing movements have mobilized to support liberal democracy in Venezuela and elsewhere. ${ }^{2}$ The grassroots right might even sometimes be a stabilizing, democratizing force, giving rightist actors a stake in the democratic system, as well as connecting them to partisan elites (Boas and Smith 2019; Boas 2021; Smith 2019a). 


\section{How Does the Grassroots Right MOBILIZE?}

The grassroots right adopts various organizational forms, ranging from hierarchical institutional structures to loose, informal networks. For instance, the largest civil society organization in the world, the Catholic Church, has deployed its formidable networks and ideological resources to advocate rightist causes, including opposition to abortion and LGBTQ+ rights, as Reuterswärd explains in this issue. ${ }^{3}$

Likewise, rapidly growing Evangelical churches have served as key nodes for right-wing activism. The grassroots right also may take the form of economic associations (Fairfield 2011); social movements, such as the anti-sex education movement Con Mis Hijos No Te Metas (Don't Mess with My Children) in Peru (Boas n.d.; Rousseau 2020); or loose coalitions organized among regional movements in Bolivia (Eaton 2007). Moreover, in this issue, both the articles by Dias, von Bülow, and Gobbi and by Gold and Peña describe how social media-based (even anonymous) networks framed issues and drove large cycles of protest, despite minimal formal organization. Right-wing individuals have also mobilized through participatory institutions, instead of forming organizations or movements, to promote police repression of marginalized groups in Brazil (González and Mayka n.d.). Often, activists coordinate through what Jessica Rich (2020) calls "federative coalitions," uniting diverse groups into a hierarchical structure for targeted campaigns while maintaining the flexibility of networks.

\section{Strategies and Tactics}

As a consequence of its organizational diversity, the grassroots right deploys a range of mobilizational tactics, including ones traditionally associated with the left in Latin America. Historically, the right leveraged its superior resources and networks to exert influence through institutional channels, from the military to bureaucratic politics to the partisan arena (Bowen 2014; Loxton 2014; Power 2000; Schneider 2004). Moreover, right-wing activists often turned against democracy and toward armed violence when they saw democratic politics as inadequate for interest representation (Payne 2000). Democracy was most stable in places where strong rightist parties came to support democratic institutions, while the defection of the right destabilized democratic regimes in other countries (Gibson 1996). In the twenty-first century, however, these channels narrowed, as democratization led to an increasing distance between military and political actors, and as leftist governments came to power.

The right has added new forms of contentious mobilization to its repertoire, including blockades and street protests. In 2008, for instance, Argentine rural agricultural producers made international headlines by blockading highways to stop tax increases, imitating a tactic developed a few years earlier by the piqueteros (Fairfield 2011; Richardson 2009, 250-51). In Brazil, a cycle of protest that began in 2013 (Alonso and Mische 2017) eventually culminated in massive protests to impeach Dilma Rousseff (Dias et al. this issue; Gold and Peña this issue). Meanwhile, partic- 
ipation in large-scale street demonstrations, such as the annual, Evangelical-dominated March for Jesus in several countries, has helped to construct the politicized identities necessary for subsequent activism. This shift is seen in public opinion data from the AmericasBarometer. Across the region as a whole, participation in protests remained slightly more common among citizens on the left than on the right, even in 2018. However, the Pearson correlation coefficient between protest participation and ideology dropped from .13 in 2006 to .06 in 2018, indicating a growing comfort with protest on the right.

The new right's repertoire of contention still includes traditional insider strategies. For instance, Mexico's Catholic pro-life movement relied on backroom deals and campaign contributions to pass anti-abortion amendments in some state constitutions (Reuterswärd this issue; see also Zaremberg 2020). In Peru, groups linked to Catholic and Evangelical churches have drafted legislation replacing legislative references to gender with the words women and men, defined as distinct and complementary (Rousseau 2020, 30-31). Other recent instances of lobbying include efforts to promote mano dura policies in Bogotá and Argentina (Eaton 2008; Mayka 2021) and to oppose disarmament in Brazil (Bob 2012, 163-65). The right also deploys legal strategies, turning to the courts to challenge school curricula that recognize gender equity and sexual diversity in Peru (Rousseau 2020, 29) and to contest gun control restrictions in Brazil (Bob 2012, 163).

The grassroots right has inserted itself into elite-level political battles; for instance, over impeachment, peace negotiations, and legislation. Dias et al. (this issue) demonstrate how right-wing groups in Brazil used social media platforms to unify ideologically diverse individuals behind the political project to impeach Dilma Rousseff and to mobilize these individuals into street protest. Gold and Peña (this issue) show that recent cycles of protest in Argentina and Brazil produced diffuse and horizontal mass-elite linkages, mediated through social media. Similarly, Smith (2019a) argues that Evangelical clergy constitute a distinct type of interlocutor for elected politicians in Brazil; pastors can serve simultaneously as opinion leaders orienting both politicians and masses, and as brokers facilitating mass-elite linkages. As Corredor's article in this issue shows, clergy-politician relationships helped organize Colombian Evangelicals' movement to defeat a referendum on the 2016 peace deal.

Just as the grassroots right carries elite-level policy conflicts into the streets, it also mobilizes the streets to influence who occupies the halls of power. Sometimes this happens through financial support for candidates, given the deep pockets of some individuals on the right. In this issue, for instance, Reuterswärd argues that campaign donations help explain successful efforts to pass anti-abortion amendments to some state constitutions in Mexico. The grassroots right is also a fertile soil for cultivating future elites. Gold and Peña (this issue), for instance, reveal that the networks organizing protests via social media in Argentina and Brazil incubated the next generation of young, social media-savvy rightist politicians. Similarly, church leadership has proven an important platform for running for office on the right in Latin America (Boas 2014, 2021; Smith 2019a). 


\section{Frames}

As part of Latin America's pluralistic social movement field, activists on the right dispute the frames of leftist movements, counterframing the advances of marginalized groups as threatening the moral foundations of society (González and Mayka n.d.; Payne and de Souza Santos 2020, 33-34). For instance, Peru's Con Mis Hijos No Te Metas frames programs to promote gender equity as assaults on the family and an intrusion into the sacred space of the home (Rousseau 2020). Despite their religious influence, these movements often rely on what Vaggione (2005) calls "strategic secularism": reframing a Christian moral agenda in universalizing terms to build broad support (see also Reuterswärd this issue).

The grassroots right also emphasizes valence issues, such as security, opposition to corruption, or patriotism. In Brazil, diverse movements - organized around issues ranging from free market economics to opposition to women's and LGBTQ+ rights to frustration with rising crime-united under an anticorruption frame to demand the impeachment of Dilma Rousseff (Dias et al. this volume). Unifying frames also link right-wing issues to patriotism and nationalism, depicting feminist and LGBTQ+ rights movements as neocolonial intrusions that threaten sovereignty (Biroli and Caminotti 2020, 3; Bob 2012, 162). Perhaps ironically, such nationalist frames are shared across transnational networks of right-wing movements (Bob 2012; Vaggione and Machado 2020, 9-10).

In addition, the grassroots right harnesses and repurposes the language of rights that has been historically favored by the left. In the twentieth century, Latin America's religious conservatives developed an alternative scholarship and narrative of human rights to contest abortion rights, one that drew on figures such as the US civil rights hero Rosa Parks to justify civil disobedience (Morgan 2014). More recently, right-wing movements frame expansions of LGBTQ+ rights as endangering children's rights under the United Nations Convention on the Rights of the Child (Biroli and Caminotti 2020; Corredor 2019), or threatening religious liberties (Payne and de Souza Santos 2020, 36). They also argue against "gender ideology" and feminism on women's rights grounds, claiming that women's advancement requires acknowledging the fundamental, complementary differences between men and women (Corredor this issue). In the field of public security, grassroots right activists contend that mano dura policing is essential to protect "deserving" citizens' rights to safety and freedom of movement (González and Mayka n.d.). Embracing rights frames yields considerable advantages, presenting rightists' demands as righteous and nonnegotiable and depicting their opponents as depraved human rights violators (Bob 2019, 14; Mayka 2021). Moreover, rights frames open up new venues for contention, given institutional obligations to protect human rights (Bob 2019, 8-9; Mayka 2021; Merry 2005; Vaggione and Machado 2020, 8-9).

Yet another effort at counterframing involves repackaging opposition to sexuality politics in scientific terms. Religious anti-abortion activists have long sought partnerships with secular groups on the basis of scientific arguments about fetal development (Morgan 2014). More recently, Santos (2019) demonstrates that 
Catholic theology of environmental protection has been adapted to justify conservative positions on gender based on supposedly biological distinctions between men and women. Even the notion of gender ideology - a term invented by rightist activists who attribute it to leftists-implies that progressives have adopted false, politicized understandings of gender in contravention of nature and science (Corredor 2019). Reuterswärd (this issue) demonstrates that appealing to biological arguments can play an important role in building support from the nondevout.

Future research is needed in these areas. First, how do the strategies, tactics, and frames of right-wing movements shift once the right comes to power? A number of studies have focused on the grassroots right's role in opposing left-wing governments and in mobilizing support for ascendant politicians on the right. As Gold and Peña (this issue) show, having right-wing allies in power can open up new opportunities for influence (as seen in Brazil under Bolsonaro) but might also demobilize and co-opt these movements (as occurred in Argentina following the election of President Mauricio Macri). Further research is needed to understand the conditions that enable sustained mobilization and influence.

We also know little about how the grassroots right interacts with institutional channels for citizen participation-especially participatory institutions on issues of concern to the right, such as child welfare policy and security (Rich et al. 2019, 13). Existing studies of participatory institutions have largely ignored these policy sectors, signaling the need for research that explores whether right-wing groups might seek to occupy these participatory institutions typically associated with the left. ${ }^{4}$ Furthermore, the crucial role of social media in the mobilization of the grassroots right raises important questions about how social media platforms have connected right-wing activists throughout the world, transformed transnational advocacy networks, and enabled the diffusion of strategic repertoires and frames across borders.

\section{What Causes The GRASSROOTS RIGHT?}

What has led to the present surge of grassroots mobilization on the right? We can immediately dismiss one possibility: the hypothesis that Latin American citizens are becoming more conservative. Analyzing AmericasBarometer data on citizens' selfplacement on a 1-10 ideological scale, where 1 indicates far left and 10 indicates far right, we see little movement in ideological self-placement in the aggregate between 2006 and 2019, across the region as a whole. In most waves, a bit over 10 percent of citizens place themselves at 10 on the scale (indicating association with the far right), and a bit more than one-third choose a position from 6 to 10..$^{5}$ Similarly, Abreu Maia et al. (2020) find no evidence that either progressive policies or conservative social movement backlash has led to growing conservatism on sexuality politics issues among Latin Americans, on net. What, then, might drive increasing mobilization? In the paragraphs that follow, we sketch a series of speculative hypotheses.

First, scholars point to long-term changes in the political opportunity structure that encourage grassroots mobilization on the right. Democratization, growing state 
capacity, and changing international norms have made recourse to military intervention and armed rebellion increasingly unattractive for societal elites dissatisfied with democratically elected leaders (Linz and Stepan 1996; Loxton 2014; Power 2000). Moreover, the secular decline of clientelism and patronage politics has restricted another channel for upper-class influence on politics (Eaton 2014, 76; Weitz-Shapiro 2014). Even behind-the-scenes bureaucratic influence may be increasingly foreclosed to rightist societal elites, as centrist and leftist administrations have bolstered authority and autonomy within the bureaucracy (Abers 2019; Rich et al. 2019, 4-5; Rich 2019). Thus, the rise of the grassroots right might indicate the maturation of Latin American democracies, in which rightist groups must compete for policy influence on relatively even footing with other civil society actors. From this perspective, it is notable that even movements with close ties to elites — such as the Mexican prochoice movements analyzed by Reuterswärd in this issue-operate through protest and lobbying instead of just relying on secret back channels.

A second hypothesis highlights the rise of Evangelical Christianity in most Latin American countries over the past several decades (Boas and Smith 2015; Chesnut 2003; Pew Research Center 2014). Both Evangelicalism and Catholicism are highly pluralistic traditions, encompassing actors ranging from the far right to the far left; neither has been associated with uniformly rightist voting and activism in Latin America (Boas and Smith 2015). Nevertheless, Evangelical politics may lean to the right of Catholic politics in the current era. Despite substantial moderation since the 1980s, Catholic progressive groups with roots in liberation theology organizing of the 1960s and 1970s remain active even today. By contrast, such movements were always weaker in Evangelicalism (Boas n.d.; Mainwaring and Wilde 1989). In addition, although Latin America's lay Evangelicals are centrists or even slightly left of Catholics on issues such as the environment, crime, and economics, they are distinctly conservative on sexuality politics - precisely the bundle of issues that has become most salient for the contemporary grassroots right (Smith and Boas 2020; Smith and Veldman 2020).

The rise of Evangelical Christianity has bolstered new mobilizing structures on the right. Evangelical converts attend church more frequently than they did as Catholics; one recent study conservatively estimated that Evangelicals and Pentecostals spend at least twice as many hours in church per year as do Catholics (Smith 2019b). Members of Evangelical and Pentecostal churches may be particularly prone to adopt shared political views, due to regular socialization, shared identities, and the salience of moralistic frames (Smith 2019a). Hence, Latin America's changing religious landscape is likely to be associated with increased exposure to religious messages with political import. Evangelical churches offer a promising mobilizing structure to channel these new grievances into political participation, as seen in Corredor's article in this issue on right-wing activism against the 2016 Colombian peace deal.

A third set of hypotheses points to the emergence of new grievances. It is not a coincidence that the grassroots right arose in the wake of Latin America's Pink Tide of the first decade of the 2000s. As left-wing administrations engaged in ambitious 
programs for redistribution and reducing economic and ethnic and racial inequality, privileged sectors had new reasons to feel threatened (Eaton 2007; Fairfield 2011). Moreover, the tragically poor performance of Venezuelan Chavismo and a more mundane frustration with corruption and economic stagnation in countries such as Argentina and Brazil triggered backlash that crossed class lines. Consequently, grassroots right protests attracted a wide range of participants, united by opposition to the policies and records of leftist administrations (Alonso and Mische 2017, 6-7; Eaton 2007, 85; Tatagiba and Galvão 2019, 79-85). Although protests initially targeted isolated grievances, they coalesced into larger movements that generated antileftist identities (Alonso and Mische 2017; Samuels and Zucco 2018; Dias et al. this issue). These new antileft identities appear to be particularly powerful among popular sector voters who had, ironically, risen out of poverty under left-leaning governments (Junge 2019; Naím 2015; Pinheiro-Machado and Mury Scalco 2020).

One particular set of grievances bears special mention: anxiety over changes in sexuality politics. Although the latter half of the twentieth century brought major changes in women's rights and family structures, the first decades of the twenty-first century ushered in previously unimaginable policy changes on abortion and samesex marriage, as well as dramatic shifts in understandings of gender and gender norms (Abreu Maia et al. 2020; Côrrea et al. 2008; Corredor 2019).

Although there is little evidence that these changes triggered a conservative backlash in public opinion in society as a whole (Abreu Maia et al. 2020), they did raise the salience of such issues for social conservatives. In a new paper, Smith and Boas (2020) show that when issues such as same-sex marriage and abortion rise in the news, religious conservatives_-including Catholics, but especially Evangelicalsincreasingly translate their conservative views into political behavior. As Reuterswärd (this issue) shows, in the Mexican state of Yucatán, anxieties about the advances made by LGBTQ+ movements triggered right-wing mobilization to expand restrictions on sexuality more broadly, including a state constitutional ban on abortion. While rightwing movements have organized in response to shifts in sexuality, they are not advocating a return to the status quo, but instead a transformed gender order that imposes new regulations on sex and sexuality (Corredor this issue).

Fourth, the rise of social media has served as a valuable resource that enables flexible and adaptable organizational forms (Castells 2012; Rich 2020, 432) and can translate grievances into collective action through framing (Dias et al. this issue). Social media may be particularly suited for rightist mobilization. As Gold and Peña argue in this issue, Latin America's leftist parties were historically more effective than rightist parties in cultivating organizational linkages with civil society. However, social media may invert that scenario, advantaging groups with deep pockets or wealthy friends who can support costs that range from "boosting" posts to funding technological access and know-how (Schradie 2019). Indeed, Gold and Peña (this issue) show that right-wing parties have formed novel forms of linkages with digital activist groups. Moreover, Dias, von Bülow, and Gobbi argue in this issue that the "reductionism" and "antagonism" of right-wing populist messages makes them particularly effective in social media. 
Fifth, the twenty-first century has brought new patterns of diffusion across borders. Growing ties among the global right wing have contributed to diffusion processes through transnational networks. One understudied topic is the mobilization of opposition to Chavismo as an organizing tool across borders, acting in parallel to the transnational coordination among leaders of the Bolivarian left. Moreover, we have also seen the emergence of transnational advocacy networks on rightist issues, including gun rights and opposition to abortion and LGBTQ+ rights (Bob 2012).

Additional studies are needed to examine empirically the relative importance of these explanations for the rise of the grassroots right as a whole or in particular cases. Moreover, it is worth noting that the literature implicitly posits that the grassroots right must be composed of different segments of society, including at a minimum economic elites, religious conservatives, and members of the popular sectors. Future research should investigate how these very different social segments have constructed networks and engaged in collective action and how they navigate the challenges of sustaining mobilization with such a heterogenous coalition. Yet another line of inquiry that so far remains underexplored, with the exception of important work by Clifford Bob (2012), relates to the international right-leaning networks - both "North-South" and within Latin America - that link the grassroots right across the region.

From a more theoretical perspective, further questions remain. One relates to the circumstances under which progressive or left-wing organizing thrives in both churches and social media. While there does appear to be an elective affinity between these mobilizing platforms and rightist issues and identities, a long history of leftist organizing in both churches and social media leaves no doubt that these platforms are far from hegemonic for the right. Theoretically informed explanations of the multivalent nature of these organizing platforms in Latin America could provide an important contribution to the literature.

\section{WHAT IS THE IMPACT OF THE GRASSROOTS RIGHT?}

The grassroots right has had varying impacts on a range of outcomes related to public policy and democracy, including legislation, social citizenship rights, political parties and party linkages, and polarization. The grassroots right's track record on legislation related to public policy has been mixed so far, often disappointing to newly mobilized rightist citizens and civil society groups. ${ }^{6}$ For instance, following the legalization of abortion in Mexico City, anti-abortion movements were able in short order to get anti-abortion constitutional amendments passed in 19 (out of 32) state constitutions in Mexico-but failed to do so in other states (Reuterswärd this issue; Zaremberg 2020). In Colombia, right-wing activists mobilized fears over gender ideology to defeat a popular referendum to approve a peace deal with the FARC guerrilla group. Yet this movement failed to stop the deal in Congress or even to significantly change the gender-sensitive language in the peace plan (Corredor this issue). Most recently, pro-choice activists outmaneuvered the anti-abortion movement in Argentina when abortion at up to 14 weeks of pregnancy was legalized. 
It is impossible to explain the success or failure of the grassroots right without also considering the strategies, resources, and frames deployed by progressive movements. In the case of the Argentine abortion legalization, for instance, the failure of the grassroots right was the flip side of the success of feminist activists. Feminist movements' use of frames related to public health and social justice for poor women proved to be more effective than pro-life narratives about the human rights of the unborn (Daby and Moseley 2021; Morgan 2014). Just as the policy successes of leftwing governments may restrict the policy alternatives of subsequent rightist leaders (Niedzwiecki and Pribble 2017), the actions taken by left-wing movements may constrain the strategies and impact of movements on the right. We need more empirically careful and theoretically informed case studies to begin to draw general conclusions about the relative strengths of the grassroots right and progressive groups in such battles and how the actions of each side change the political calculus of the other. One promising case study may be Chile's constitutional rewriting process, which will certainly draw both rightist and leftist mobilizing.

Additional work is needed to understand how allies inside the state shape the influence of right-wing groups. As the 2019 special issue of this journal on the "politics of participation in Latin America" (Rich et al. 2019) emphasizes, allies within the bureaucracy and judiciary might amplify the policy impact of civil society groups. These allies may support the aims of the grassroots right, as seen in Corredor's analysis of the peace process in Colombia. Likewise, actors such as medical professionals, who are tasked with implementing policies such as abortion, can coordinate with rightwing movements to block progressive changes (Morgan 2014; Pérez Betancur and Rocha-Carpiuc 2020). Yet progressive bureaucrats can also block the social change envisioned by the grassroots right (Abers 2019). In other words, even if the grassroots right succeeds in electing its allies, state actors may resist conservative retrenchment. Further theoretical and empirical work remains for scholars to disentangle the complex interactions within the state that shape the impact of the grassroots right in both advocating legislative change and influencing policy implementation.

Turning from discrete policy changes to an overall view, how has the grassroots right impacted Latin American democracy? We would argue that the grassroots right has enhanced democratic quality in some instances by providing representation and opportunities for participation to groups that historically had been excluded, such as Evangelicals (Boas 2021; Boas and Smith 2019; Smith 2019a). This position is not dissimilar to an older argument that rightist participation in democratic politics forestalled military coups and armed right-wing subversive activities by giving those on the right a stake in the democratic system (Loxton 2014; Payne 2000; Gibson 1996). In addition, in countries led by the "radical" or Bolivarian left, right-wing activists have, at times, mobilized to support liberal democratic institutions and checks and balances.

Yet the grassroots right also has nonetheless potentially pernicious effects on democracy, particularly when it seeks to restrict the rights of marginalized groups. Indeed, Pentecostal and Evangelical groups have been the most prominent opponents of LGBTQ+ rights and inclusion in Latin America (Corrales 2017). Right- 
wing activists have demanded repressive policing that violates the civil liberties and procedural rights of marginalized communities, even rejecting the very notion that these groups should have citizenship rights (González and Mayka n.d.). In some countries of the region, grassroots right mobilization has accompanied societal trends toward an increasingly Manichean polarization. Yet leftists have also abetted polarization in Latin America, which is why we argue that both populism and authoritarianism are orthogonal to left-right divides in Latin America. Overall, we see these trends toward increasing polarization, populism, and illiberalism as worrisome for the long-term stability of Latin American democracy.

These tensions pose an urgent research agenda for future scholars. What circumstances encourage the representation of diverse ideological perspectives without exacerbating populism, polarization, and illiberalism? Under what circumstances and in what contexts can grassroots right mobilization be a force for stability and inclusion without sacrificing the rights of other groups? One line of investigation that may be promising focuses on the potential of "rights" frames for bridging divides. In the US context, for instance, Lewis (2017) shows that Evangelicals' strategic adoption of rights-based framing in anti-abortion mobilization has had positive downstream consequences for democracy. Such frames have warmed Evangelicals' attitudes toward rights and democracy themselves, and can encourage US Evangelicals to become more tolerant of groups they oppose (Lewis 2017). Future work should investigate the roles of frames and political context in inclusion and moderation of the grassroots right in Latin America.

\section{OVERVIEW OF ARTICLES IN THIS SPECIAL SECTION}

The four articles review recent developments in mobilization by the grassroots right, examining a range of countries (Argentina, Brazil, Colombia, Mexico) and issues (LGBTQ+ rights, abortion, peace processes, corruption, removing elected officials from office). They highlight innovations in strategies, tactics, and frames and generate new hypotheses about the causes and consequences of the grassroots right in Latin America.

The article by Camilla Reuterswärd explores the impact of right-wing movements through a comparison of struggles over abortion in two Mexican states. In Yucatán, pro-life movements succeeded in getting a restrictive anti-abortion law passed, while a comparable initiative failed in Hidalgo. Both pro-life movements framed their demands in biological and bioethics terms while cloaking the role of the Catholic Church. To explain their varied success, Reuterswärd points to movement resources, leveraged through tight networks between religious organizations, economic elites, and politicians. The hegemonic Yucatán Catholic Church mobilized moral and financial resources to pressure politicians to pursue anti-abortion reform. Conversely, the church in Hidalgo lacked such ties, creating an opening for feminist groups' demands. Reuterswärd signals the roles of networks, material resources, and frames in explaining the impact of the grassroots right. 
The article by Elizabeth Corredor also examines the policy impact of the grassroots right, this time in opposition to Colombia's 2016 peace agreement. Opponents of "gender ideology" objected to an intersectional approach used in the peace deal that recognized diverse sexual identities and promoted gender equality. Antigender activists creatively framed their opposition using human rights discourses, portraying a gender-sensitive approach as an assault on freedom of religion, the right to life, the right to marriage and a family, and the right to dignity. Using careful content analysis, however, Corredor demonstrates that anti-gender activists ultimately failed to strike references to gender sensitivity from the final document; nor could they stop its legislative passage, despite close ties to prominent politicians. One implication is that backlash against progressive causes does not necessarily succeed but can spark new dynamics of contention as movements and countermovements respond to each other.

Tayrine Dias, Marisa von Bülow, and Danniel Gobbi illustrate framing processes via an impressive content analysis of thousands of Facebook posts made by five right-wing groups during the 2017 campaign to impeach Brazilian president Dilma Rousseff. They show that despite marked ideological differences, these five groups coordinated messages that cast blame for endemic corruption on the ruling Workers' Party and framed impeachment as the necessary corrective. This article highlights the crucial role of social media in creating a shared interpretation of grievances among right-wing individuals who may share few offline network ties and hold diverse political views.

In their study, Tomás Gold and Alejandro Peńa further probe the power of social media in right-wing activism, comparing protest cycles in Argentina (201213) and Brazil (2013-16). Gold and Peña argue that right-wing parties have developed novel forms of linkages with voters by aligning with digital activist groups, leading those parties to embrace protest and other forms of contentious politics that were historically the purview of leftist and other labor-based parties. Although these linkage strategies enabled right-wing parties to rise to power in both countries, digital activists maintained an important role under rightist rule in Brazil while being displaced in Argentina. This divergence raises important questions about how digital linkage strategies endure over time and their potential to yield institutional influence for the grassroots right.

Together, the four essays shed new light on the role of the grassroots right in politics and raise important questions for further study. Right-wing activists have emerged as central figures in contemporary struggles over public policy, human rights, and partisan politics. We hope this special section serves as a call for future research that helps make sense of the crucial role of the grassroots right in Latin American democracies. 


\section{NOTES}

1. In emphasizing mobilized support for rightist issues and identities, our definition excludes militarized local right-leaning organizations whose primary purpose is criminal or extralegal territorial control, such as the milícias that dominate many urban neighborhoods in Brazil (Manso 2020). However, it does include right-wing groups that employ violent strategies.

2. During the early years of the Hugo Chávez presidency, Venezuela's opposition undertook a number of antidemocratic moves (Gamboa 2017). As the Venezuelan regime hardened, right-wing opposition groups shifted their approach to support the checks and balances involved in democracy. However, authoritarian strands persist among some in the opposition.

3. The Catholic Church's issue priorities are nonetheless diverse and conflictual, and defy easy categorization on the left-right spectrum (Hagopian 2008; Hale 2019; Warner 2000).

4. Important exceptions include the work by Yanilda González on participatory security councils (González 2019).

5. This analysis is of the combined 2008 to 2018-2019 AmericasBarometer file. For data access, see www.americasbarometer.org. These estimates include people who choose nonresponse to the ideology question, given evidence that understanding of and ability to locate oneself on the ideological scale is uneven and nonrandomly distributed in Latin America (Ames and Smith 2010; Batista Pereira 2020; Zechmeister and Corral 2013). The conclusion is roughly similar if we examine only citizens choosing a position from 7 to 10 .

6. Although we will not address this topic here for the sake of space, it is worth noting that the grassroots right has not had overwhelming success in electoral politics, either. The 2018 election of Jair Bolsonaro in Brazil is the new right's most prominent electoral success, but the 2018 second-round loss of the Evangelical, anti-gender-ideology pastor Fabricio Alvorado in Costa Rica may more accurately reflect the general fate of the grassroots right at the ballot box in Latin America.

\section{REFERENCES}

Abers, Rebecca. 2019. Bureaucratic Activism: Pursuing Environmentalism Inside the Brazilian State. Latin American Politics and Society 61, 2: 21-44.

Abreu Maia, Lucas de, Albert Chiu, and Scott Desposato. 2020. Persuaded by Policy: Public Opinion Responses to Granting LGBT Rights in Latin America. SSRN Scholarly Paper ID 3535833. Rochester: Social Science Research Network.

Alonso, Angela, and Ann Mische. 2017. Changing Repertoires and Partisan Ambivalence in the New Brazilian Protests. Bulletin of Latin American Research 36, 2: 144-59.

Ames, Barry, and Amy Erica Smith. 2010. Knowing Left from Right: Ideological Identification in Brazil, 2002-2006. Bulletin of Latin American Research 36, 2: 3-38.

Baldez, Lisa. 2002. Why Women Protest: Women's Movements in Chile. New York: Cambridge University Press.

Batista Pereira, Federico. 2020. Non causa pro causa: o voto de direita e esquerda no Brasil. Opinão Pública 26, 2: 154-79.

Biroli, Flávia, and Mariana Caminotti. 2020. The Conservative Backlash Against Gender in Latin America. Politics \& Gender 16, 1: 1-6.

Blofield, Merike. 2008. Women's Choices in Comparative Perspective: Abortion Policies in Late-developing Catholic Countries. Comparative Politics 40, 4: 399-419.

Boas, Taylor. 2014. Pastor Paulo vs. Doctor Carlos: Professional Titles as Voting Heuristics in Brazil. Journal of Politics in Latin America 6, 2: 39-72. 
. 2021. Expanding the Public Square: Evangelicals and Electoral Politics in Latin America. In The Inclusionary Turn in Latin American Democracies, ed. Diana Kapiszewski, Steven Levitsky, and Deborah Yashar. New York: Cambridge University Press. 362-97. - n.d. Evangelicals and Electoral Politics in Latin America: A Kingdom of This World. Unpublished mss.

Boas, Taylor, and Amy Erica Smith. 2015. Religion and the Latin American Voter. In The Latin American Voter: Pursuing Representation and Accountability in Challenging Contexts, ed. Ryan E. Carlin, Matthew E. Singer, and Elizabeth Zechmeister. Ann Arbor: University of Michigan Press. 99-121.

- 2019. Looks Like Me, Thinks Like Me: Descriptive Representation and Opinion Congruence in Brazil. Latin American Research Review 54, 2: 310-28.

Bob, Clifford. 2012. The Global Right Wing and the Clash of World Politics. New York: Cambridge University Press.

. 2019. Rights as Weapons: Instruments of Conflict, Tools of Power. Princeton: Princeton University Press.

Bowen, James. 2011. The Right in "New Left" Latin America. Journal of Politics in Latin America 3, 1: 99-124.

2014. The Right and Nonparty Forms of Representation and Participation: Bolivia and Ecuador Compared. In Luna and Rovira Kaltwasser 2014b. 94-116.

Castells, Manuel. 2012. Networks of Outrage and Hope: Social Movements in the Internet Age. Cambridge: Polity Press.

Chesnut, R. Andrew. 2003. Competitive Spirits: Latin America's New Religious Economy. New York: Oxford University Press.

Cohen, Mollie J., Amy Erica Smith, Mason W. Moseley, and Matthew Layton. Forthcoming. Winners' Consent: Citizen Commitment to Democracy when Illiberal Candidates Win Elections. American Journal of Political Science.

Corrales, Javier. 2017. Understanding the Uneven Spread of LGBT Rights in Latin America and the Caribbean, 1999-2013. Journal of Research in Gender Studies 7, 1: 52-82.

Côrrea, Diego Sanches. 2015. Os custos eleitorais do Bolsa Família: reavaliando seu impacto sobre a eleiçấo presidencial de 2006. Opinão Pública 21, 3: 514-34.

Côrrea, Sonia, Rosalind Petchesky, and Richard Parker. 2008. Sexuality, Health, and Human Rights. New York: Routledge.

Corredor, Elizabeth. 2019. Unpacking Gender Ideology and the Global Right's Anti-gender Countermovement. Signs: Journal of Women in Culture and Society 44, 3 (Spring): 61338.

Cowan, Benjamin. 2014. "Nosso terreno": crise moral, política evangélica e a formação da "Nova Direita” brasileira. Varia Historia 30, 52: 101-25.

Daby, Mariela, and Mason Moseley. 2021. Feminist Mobilization and the Abortion Debate in Latin America: Lessons from Argentina. Politics \& Gender, First View, February 9. DOI 10.1017/S1743923X20000197

Díez, Jordi. 2015. The Politics of Gay Marriage in Latin America. New York: Cambridge University Press.

Eaton, Kent. 2007. Backlash in Bolivia: Regional Autonomy as a Reaction Against Indigenous Mobilization. Politics and Society 35, 1: 71-102.

- 2008. Paradoxes of Police Reform: Federalism, Parties, and Civil Society in Argentina's Public Security Crisis. Latin American Research Review 43, 3: 5-32.

. 2014. New Strategies of the Latin American Right: Beyond Parties and Elections. In Luna and Rovira Kaltwasser 2014b. 75-93. 
Encarnación, Omar. 2016. Out in the Periphery: Latin America's Gay Rights Revolution. New York: Oxford University Press.

Fairfield, Tasha. 2011. Business Power and Protest: Argentina's Agricultural Producers Protest in Comparative Context. Studies in Comparative International Development 46, 4: 424-53.

Feres Júnior, João, and Verônica Toste Daflon. 2015. A nata e as cotas raciais: genealogia de um argumento público. Opinão Pública 21, 2: 238-67.

Gamboa, Laura. 2017. Opposition at the Margins: Strategies Against the Erosion of Democracy in Venezuela. Comparative Politics 49, 4: 457-77.

Gibson, Christopher. 2019. Movement-driven Development: The Politics of Health and Democracy in Brazil. Stanford: Stanford University Press.

Gibson, Edward. 1996. Class and Conservative Parties: Argentina in Comparative Perspective. Baltimore: Johns Hopkins University Press.

González, Victoria, and Karen Kampwirth, eds. 2001. Radical Women in Latin America: Left and Right. University Park: Pennsylvania State University Press.

González, Yanilda. 2019. Participation as a Safety Valve: Police Reform Through Participatory Security in Latin America. Latin American Politics and Society 61, 2: 68-92.

González, Yanilda, and Lindsay Mayka. n.d. Democratic Participation in Policing and the Reproduction of Asymmetric Citizenship: The Contradictions of Participatory Security in São Paulo, Brazil. Unpublished mss.

Hagopian, Frances. 2008. Latin American Catholicism in an Age of Religious and Political Pluralism: A Framework for Analysis. Comparative Politics 40, 2: 149-68.

Hale, Christopher. 2019. Catholic Church Advocacy in Latin America. In The Oxford Research Encyclopedia of Politics. New York: Oxford University Press. https://oxfordre.com/politics/

Herrera, Veronica, and Lindsay Mayka. 2020. How Do Legal Strategies Advance Social Accountability? Evaluating Mechanisms in Colombia. Journal of Development Studies 56, 8: 1437-54.

Hochstetler, Kathryn, and Margaret Keck. 2007. Greening Brazil: Environmental Activism in State and Society. Durham: Duke University Press.

Holland, Alisha. 2013. Right on Crime? Conservative Party Politics and Mano Dura Policies in El Salvador. Latin American Research Review 48, 1: 44-67.

Htun, Mala. 2003. Sex and the State. New York: Cambridge University Press.

Junge, Benjamin. 2019. "Our Brazil Has Become a Mess": Nostalgic Narratives of Disorder and Disinterest as a "Once-rising Poor" Family from Recife, Brazil, Anticipates the 2018 Elections. Journal of Latin American and Caribbean Anthropology 24, 4: 914-31.

Lacerda, Marina Basso. 2019. O novo conservadorismo brasileiro: de Reagan a Bolsonaro. Porto Alegre: Editora Zouk.

Layton, Matthew, Amy Erica Smith, Mason W. Moseley, and Mollie J. Cohen. 2021. Demographic Polarization and the Rise of the Far Right: Brazil's 2018 Presidential Election. Research \& Politics, January 28. DOI 10.1177/2053168021990204

Lewis, Andrew. 2017. The Rights Turn in Conservative Christian Politics: How Abortion Transformed the Culture Wars. New York: Cambridge University Press.

Linz, Juan, and Alfred Stepan. 1996. Toward Consolidated Democracies. Journal of Democracy 72 , April: $14-33$.

Loxton, James. 2014. The Authoritarian Roots of New Right Party Success in Latin America. In Luna and Rovira Kaltwasser 2014b. 117-40.

. 2016. Authoritarian Successor Parties and the New Right in Latin America. In Challenges of Party-building in Latin America, ed. Steven Levitsky, Loxton, Brandon Van Dyck, and Jorge Domínguez. New York: Cambridge University Press. 245-72. 
Lucero, José Antonio. 2008. Struggles of Voice: The Politics of Indigenous Representation in the Andes. Pittsburgh: University of Pittsburgh Press.

Luna, Juan Pablo. 2014. Segmented Representation: Political Party Strategies in Unequal Democracies. New York: Oxford University Press.

Luna, Juan Pablo, and Cristóbal Rovira Kaltwasser. 2014a. The Right in Contemporary Latin America: A Framework for Analysis. In Luna and Rovira Kaltwasser 2014b. 1-22.

Luna, Juan Pablo, and Cristóbal Rovira Kaltwasser, eds. 2014b. The Resilience of the Latin American Right. Baltimore: Johns Hopkins University Press.

Mainwaring, Scott, and Alexander Wilde, eds. 1989. The Progressive Church in Latin America. Notre Dame: University of Notre Dame Press.

Manso, Bruno Paes. 2020. A república das milicias: dos esquadrôes da morte à era Bolsonaro. São Paulo: Todavia.

Mayka, Lindsay. 2019. Building Participatory Institutions in Latin America: Reform Coalitions and Institutional Change. New York: Cambridge University Press.

- 2021. The Power of Human Rights Frames in Urban Security: Lessons from Bogotá. Comparative Politics 53, 3. DOI 10.5129/001041521X16115808641104

Merry, Sally Engle. 2005. Human Rights and Gender Violence: Translating International Law into Local Justice. Chicago: University of Chicago Press.

Middlebrook, Kevin, ed. 2000. Conservative Parties, the Right, and Democracy in Latin America. Baltimore: Johns Hopkins University Press.

Morgan, Lynn M. 2014. Claiming Rosa Parks: Conservative Catholic Bids for "Rights" in Contemporary Latin America. Culture, Health \& Sexuality 16, 10: 1245-59.

Naím, Moisés. 2015. The Coming Turmoil in Latin America. The Atlantic, October 8.

Niedzwiecki, Sara, and Santiago Anria. 2019. Participatory Social Policies: Diverging Patterns in Brazil and Bolivia. Latin American Politics and Society 61, 2: 115-37.

Niedzwiecki, Sara, and Jennifer Pribble. 2017. Social Policies and Center-Right Governments in Argentina and Chile. Latin American Politics and Society 59, 3: 72-97.

Paschel, Tianna. 2016. Becoming Black Political Subjects: Movements and Ethno-racial Rights in Colombia and Brazil. Princeton: Princeton University Press.

Payne, Leigh. 2000. Uncivil Movements: The Armed Right Wing and Democracy in Latin America. Baltimore: Johns Hopkins University Press.

Payne, Leigh, and Andreza Aruska de Souza Santos. 2020. The Right-wing Backlash in Brazil and Beyond. Politics \& Gender 16, 1: 32-38.

Pérez Betancur, Verónica, and Cecilia Rocha-Carpiuc. 2020. The Postreform Stage: Understanding the Backlash Against Sexual Politics in Latin America. Politics \& Gender 16, 1: 11-18.

Pew Research Center. 2014. Religion in Latin America: Widespread Change in a Historically Catholic Region. Washingon, DC: Pew Research Center. November 13.

Pinheiro-Machado, Rosana, and Lucia Mury Scalco. 2020. From Hope to Hate: The Rise of Conservative Subjectivity in Brazil. HAU: Journal of Ethnographic Theory 10, 1: 21-31.

Power, TImothy J. 2000. The Political Right in Postauthoritarian Brazil: Elites, Institutions, and Democratization. University Park: Pennsylvania State University Press.

Rich, Jessica. 2019. State-sponsored Activism: Bureaucrats and Social Movements in Democratic Brazil. New York: Cambridge University Press.

- 2020. Organizing Twenty-First-Century Activism: From Structure to Strategy in Latin American Social Movements. Latin American Research Review 55, 3: 430-44.

Rich, Jessica, Lindsay Mayka, and Alfred Montero. 2019. The Politics of Participation in Latin America: New Actors and Institutions. Latin American Politics and Society 61, 2: $1-20$. 
Richardson, Neal. 2009. Export-oriented Populism: Commodities and Coalitions in Argentina. Studies in Comparative International Development 44, 3: 228-55.

Roberts, Kenneth. 2014. Changing Course: Parties, Populism, and Political Representation in Latin America's Neoliberal Era. New York: Cambridge University Press.

Rousseau, Stéphanie. 2020. Antigender Activism in Peru and Its Impacts on State Policy. Politics \& Gender 16, 1: 25-32.

Samuels, David J., and Cesar Zucco. 2018. Partisans, Antipartisans, and Nonpartisans: Voting and Behavior in Brazil. New York: Cambridge University Press.

Santos, Renan William dos. 2019. Direitos da natureza e deveres religiosos: tensões entre a ecologia Católica e movimientos ambientalistas seculares. Religião \& Sociedade 39 (October): 78-99.

Schneider, Ben Ross. 2004. Business Politics and the State in Latin America. New York: Cambridge University Press.

Schradie, Jen. 2019. The Revolution That Wasn't: How Digital Activism Favors Conservatives. Cambridge: Harvard University Press.

Smith, Amy Erica. 2019a. Religion and Brazilian Democracy: Mobilizing the People of God. New York: Cambridge University Press.

- 2019b. Religion, Politics, and the Secular State. In The Routledge Handbook of Brazilian Politics, ed. Barry Ames. New York: Routledge. 87-102.

Smith, Amy Erica, and Taylor Boas. 2020. Religion, Sexuality Politics, and the Transformation of Latin American Electorates. Paper presented at the Charlemos Series, University of Pittburgh, September.

Smith, Amy Erica, and Robin Globus Veldman. 2020. Evangelical Environmentalists? Evidence from Brazil. Journal for the Scientific Study of Religion 59, 2: 341-59.

Tatagiba, Luciana, and Andreia Galvão. 2019. Os protestos no Brasil em tempos de crise, 2011-2016. Opinão Pública 25, 1: 63-96.

Thayer, Millie. 2009. Making Transnational Feminism: Rural Women, NGO Activists, and Northern Donors in Brazil. New York: Routledge.

Vaggione, Juan Marco. 2005. Reactive Politicization and Religious Dissidence: The Political Mutations of the Religious. Social Theory and Practice 31, 2: 233-55.

Vaggione, Juan Marco, and Maria das Dores Campos Machado. 2020. Religious Patterns of Neoconservatism in Latin America. Politics \& Gender 16, 1: 6-10.

Vommaro, Gabriel, Sergio Morresi, and Alejandro Bellotti. 2015. Mundo PRO: anatomía de un partido fabricado para ganar. Buenos Aires: Planeta.

Warner, Carolyn M. 2000. Confessions of an Interest Group: The Catholic Church and Political Parties in Europe. Princeton: Princeton University Press.

Weitz-Shapiro, Rebecca. 2014. Curbing Clientelism in Argentina: Politics, Poverty, and Social Policy. New York: Cambridge University Press.

Wiesehomeier, Nina, and David Doyle. 2014. Profiling the Electorate: Ideology and Attitudes of Rightwing Voters. In Luna and Rovira Kaltwasser 2014b. 48-72.

Yashar, Deborah. 2005. Contesting Citizenship in Latin America: The Rise of Indigenous Movements and the Postliberal Challenge. New York Cambridge University Press.

Zaremberg, Gisela. 2020. Feminism and Conservatism in Mexico. Politics \& Gender 16, 1: $19-25$.

Zechmeister, Elizabeth, and Margarita Corral. 2013. Individual and Contextual Constraints on Ideological Labels in Latin America. Comparative Political Studies 46, 6: 675-701. 